\section{ECONOMICS}

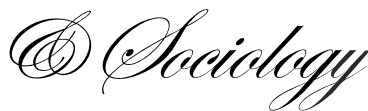

Adam P. Balcerzak,

Nicolaus Copernicus University,

Torun, Poland,

E-mail:adam.balcerzak@umk.pl

Received: January, 2016

1st Revision: March, 2016

Accepted: June, 2016

DOI: $10.14254 / 2071-$

789X.2016/9-2/1
Balcerzak, A. P. (2016), Multiple-criteria Evaluation of Quality of Human Capital in the European Union Countries, Economics and Sociology, Vol. 9, No 2, pp. 11-26. DOI: 10.14254/2071-789X.2016/9-2/1

\title{
MULTIPLE-CRITERIA EVALUATION OF QUALITY OF HUMAN CAPITAL IN THE EUROPEAN UNION COUNTRIES
}

\begin{abstract}
Successful policies and programs leading to improvement of quality of human capital in the context of knowledge-based economy are currently considered as the basic condition for keeping global competitiveness of the European economy. It has been pointed as one of the most important aims of Europe 2020 strategy. In the EU all the countries are obliged to implement national strategies that should result in reaching that aims. As a result, it is necessary to compare countries' results, which can be useful for pointing the best practices and effective policy guidelines. Thus, the main aim of the article is to provide a multiple-criteria analysis of the quality of human capital in the EU countries at macroeconomic level. Special attention is given here to the results obtained by new member states of the EU. The research is done for the years 2001-2012. Additionally, it gives some insight on the possible influence of the global financial crisis on the dynamics of the quality of human capital in the EU countries. Data from Eurostat is used. Hellwig's method of taxonomic measure of development with the constant pattern (ideal solution) for the entire period is applied in the research. The Hellwig's method is very close to TOPSIS method, which is based on a concept of similarity to ideal solution and which is currently commonly applied in multiple-criteria decision-making (MCDM). After obtaining the relative measure for the quality of human capital, the countries were grouped into homogenous subsets with application of natural breaks method. The main advantages of the applied methods are high elasticity and methodological simplicity, which is crucial in the case of multiple-criteria decision analysis (MCDA).
\end{abstract}

JEL Classification: C38, E24

Keywords: multiple-criteria decision-making (MCDM), multiplecriteria decision analysis (MCDA), Hellwig's method, human capital, European Union.

\section{Introduction}

Quality of human capital (QHC), both at microeconomic and macroeconomic level, is currently considered as the main growth factor in developed economies. The process of 
creation of high value added in the reality of global competitive knowledge-based economy is not possible without constant effort to improve the QHC. Thus, from the long term perspective effective policies supporting multifactor development of the QHC in the context of knowledge-based economy make the condition for keeping global competitiveness of every developed economy. In the European economy it has been stated as one of the most important aims of the Europe 2020 strategy (Balcerzak, 2015, pp. 190-2010; European Commission, 2010; Hobza \& Mourre, 2010). However, the economic role of the QHC is not only crucial form the perspective of long term macroeconomic development. For example in the short term it influences the situation on the labour markets (Müller-Fraczek \& Pietrzak, 2011, pp. 205-209; Pietrzak \& Balcerzak, 2016a; Balcerzak (ed.), 2009; Balcerzak \& Żurek, 2011, pp. 3-14), the economic and social cohesion of regions and cities (Wilk et al., 2013, pp. 124132; Pietrzak et al., 2014, pp. 135-144) or countries fiscal sustainability (Balcerzak et al., 2016, pp. 483-496; Balcerzak and Rogalska, 2016, pp. 271-282). Thus, the research on the QHC is important both form long and short term perspective.

In the EU all governments implement national strategies that should support improvement of the QHS. In this context, it is necessary to compare countries' results, which can be useful for pointing the best practices and effective policy guidelines in the field. Thus, the main objective of the article is to provide a multiple-criteria analysis of the QHC in the EU countries at macroeconomic level. In the research the special attention is given to the results obtained by new member states of the EU. The research was based on the Eurostat data for the years 2001-2012. Furthermore, the analysis was done for two sub-periods 20012007 and 2007-2012. This approach enables to provide some insight on the probable influence of the global financial crisis on the changes of the QHC in the European economy.

Additional operational aim of the paper is to provide input data on the QHC that can be used in econometric modeling of macroeconomic determinants of development and growth of European economies (see Pietrzak \& Balcerzak, 2016b; Balcerzak \& Pietrzak, 2016a, 2016b; Balcerzak \& Pietrzak, 2015, pp. 93-106; Balcerzak, 2009, pp. 711-739). The article is a continuation of previous research of the author in the field (Balcerzak \& Pietrzak, 2016c; Balcerzak, 2011, pp. 456-467).

\section{Data and Selection of Diagnostic Variables}

The QHC analyzed form macroeconomic perspective must be treated as complex multivariate phenomenon. It should be quantified with application of taxonomy tools and multiple-criteria decision analysis (MCDA) methodological approach (see: Balcerzak \& Pietrzak, 2016d; Kunasz, 2009, pp. 35-48; Pawlas, 2009, pp. 21-31; Pietrzak \& Balcerzak, 2016c; Wronowska, 2009, pp. 32-45; David, \& Goddard Lopez, 2001).

In the case of every multiple-criteria analysis the most significant problem is the choice of diagnostic variables that are used in the quantification of a given phenomenon. It must be stressed that the final results are always strongly influenced by the choice of the diagnostic variables (Gostkowski, 1972, pp. 15-17). This is especially important in the case of difficult to measure and quite often qualitative factor such as the QHC. As a results, in the first stage based on the review of literature related to previous research on the QHC a set of preliminary variables was selected, which in the second stage were verified with the application of formal taxonomic criteria of information value (Zeliaś (ed.), 2000, pp. 127-133).

In regard to the first stage, based on the theoretical models mostly proposed by the economists working on endogenous growth theory (Cichy, 2009; Cichy \& Malaga, 2006, pp. 5-24; Florczak, 2007, pp. 112-167), empirical research (Wronowska, 2015, pp. 33-45; OkońHorodyńska \& Wisła (eds.), 2010; Herbst (ed.), 2007; Laroche et al., 1999, pp. 87-100) and the data proposed by Eurostat 26 factors presented in Table 1 were chosen for a sets of 
preliminary diagnostic variables. As the EU economies must compete in the reality of global knowledge-based economy (Madrak-Grochowska, 2015, pp. 7-21; Libertowska, 2014, pp. 93107; Stankiewicz \& Moczulska, 2015, pp. 37-51; Ciborowski, 2014, pp. 57-72; SachpaziduWójcicka, 2014, pp. 93-107) at this stage the choice of potential diagnostic variables was strongly influenced by the macroeconomic and structural requirements created by this phenomenon. The variables were classified as stimulants and dis-stimulants, where the first once are treated as the factors that improve the QHC and the second once describe the aspects that hamper it.

Table 1. Set of potential diagnostic variables used in the research

\begin{tabular}{|c|c|c|}
\hline$x_{j t}$ & Potential diagnostic variable & $\begin{array}{l}\text { Classification of } \\
\text { the variable }\end{array}$ \\
\hline 1 & 2 & 3 \\
\hline$x_{1 t}$ & Effectiveness of lobur force - product per hour worked & Stimulant \\
\hline$x_{2 t}$ & Effectiveness of lobur force - product per person employed & Stimulant \\
\hline$x_{3 t}$ & $\begin{array}{l}\text { Employment rate among people in the age } 20 \text { to } 64 \text { years (\% of } \\
\text { population) }\end{array}$ & Stimulant \\
\hline$x_{4 t}$ & $\begin{array}{l}\text { Employment rate among people in the age } 55 \text { to } 64 \text { years (\% of } \\
\text { population) }\end{array}$ & Stimulant \\
\hline$x_{5 t}$ & Unemployment rate (annual average \%) & Dis-stimulants \\
\hline$x_{6 t}$ & Long-term unemployment - \% of active population & Dis-stimulants \\
\hline$x_{7 t}$ & Average age of leaving labor force & Stimulant \\
\hline$x_{8 t}$ & $\begin{array}{l}\text { Low educational attainment }-\% \text { of population with less than primary, } \\
\text { primary and lower secondary education in the age } 18 \text { to } 24 \text {. }\end{array}$ & Dis-stimulants \\
\hline$x_{9 t}$ & $\begin{array}{l}\text { Educational attainment - \% of population in the age } 25 \text { to } 34 \text { with } \\
\text { tertiary education }\end{array}$ & Stimulant \\
\hline$x_{10 t}$ & $\begin{array}{l}\text { Participation rate in education and training for population in the age from } \\
25 \text { to } 64 \text { years }\end{array}$ & Stimulant \\
\hline$x_{11 t}$ & $\begin{array}{l}\text { Government investment in human capital - expenditure on education as } \\
\% \text { of GDP }\end{array}$ & Stimulant \\
\hline$x_{12 t}$ & $\begin{array}{l}\text { Total intramural R\&D expenditure (GERD) percentage of gross domestic } \\
\text { product (GDP) }\end{array}$ & Stimulant \\
\hline$x_{13 t}$ & $\begin{array}{l}\text { Human resources in science and technology as a share of total labour } \\
\text { force }\end{array}$ & Stimulant \\
\hline$x_{14 t}$ & $\begin{array}{l}\text { Patent applications to the European Patent Office }- \text { number of } \\
\text { applications per million inhabitants }\end{array}$ & Stimulant \\
\hline$x_{15 t}$ & $\begin{array}{l}\text { Patents granted by the United States Patent and Trademark Office - } \\
\text { number of patents per million inhabitants }\end{array}$ & Stimulant \\
\hline$x_{16 t}$ & $\begin{array}{l}\text { Tertiary graduates in science and technology per } 1000 \text { inhabitants aged } \\
20-29 \text { years }\end{array}$ & Stimulant \\
\hline$x_{17 t}$ & $\begin{array}{l}\text { Individuals' level of Internet skills - individuals who have carried out the } \\
\text { Internet related activities - percentage of the total number of individuals } \\
\text { aged } 16 \text { to } 74\end{array}$ & Stimulant \\
\hline$x_{18 t}$ & $\begin{array}{l}\text { Individuals' level of computer skills - individuals who have carried out } \\
\text { the computer related activities - percentage of the total number of } \\
\text { individuals aged } 16 \text { to } 74\end{array}$ & Stimulant \\
\hline$x_{19 t}$ & $\begin{array}{l}\text { E-Commerce via Internet - percentage of enterprises' total turnover from } \\
\text { E-commerce via Internet }\end{array}$ & Stimulant \\
\hline$x_{20 t}$ & $\begin{array}{l}\text { E-government usage by individuals by gender }- \text { percentage of } \\
\text { individuals aged } 16 \text { to } 74 \text { using the Internet for interaction with public } \\
\text { authorities }\end{array}$ & Stimulant \\
\hline$x_{21 t}$ & ICT expenditure - percentage of GDP & Stimulant \\
\hline
\end{tabular}




\begin{tabular}{clc}
\hline 1 & \multicolumn{1}{c}{2} & 3 \\
\hline$x_{22 t}$ & $\begin{array}{l}\text { High-tech exports - exports of high technology products as a share of } \\
\text { total exports }\end{array}$ & Stimulant \\
\hline$x_{23 t}$ & Life expectancy at birth & Stimulant \\
\hline$x_{24 t}$ & Healthy life years expectancy at birth & Stimulant \\
\hline$x_{25 t}$ & Severe material deprivation - \% of population & Dis-stimulants \\
\hline$x_{26 t}$ & Population at-risk-of-poverty - \% of population & Dis-stimulants \\
\hline
\end{tabular}

Source: own work.

In regard to the second stage, after the analysis of completeness of the data for the whole analytical period, all the variables were evaluated from the perspective of their information value. It is assumed that in the case of multiple-criteria analysis the diagnostic variables should be characterized with three formal statistical criteria: a) high level of variation, b) high information value, c) low level of correlation (Zeliaś (ed.), pp. 127-133; Hellwig, 1972a, pp. 69-90).

First of all, the variables used in the taxonomic research should not be similar to each other in the sense of information concerning the objects. In order to evaluate that factor the coefficient of variation is commonly used, where the variables that do not fulfill arbitrary given criterion for example such as $\varepsilon<0,1$ are eliminated from the research.

Then, the variables characterized with high information value usually reach high values with relatively great difficulty. In order to evaluate the information values of the variable the skewness coefficient can be used. It is assumed that in the case of stimulants for the important factors the distribution of the variable should be right-skewed. When in the case of stimulants the distribution is left-skewed, it means that most of the objects easily reach high values of the measure for a given factor. Thus, the variable does not differentiate the objects significantly and it should be removed from the research.

In the end, the variables should not be highly correlated, as high correlation of the diagnostic variables could result in the overlapping of information on the analyzed objects. In the case of high correlation of the variables a parametric method proposed by Hellwig can be applied, where the maximum value of correlation coefficient for the variables can be set as $r=0,8$.

Table 2. Set of final diagnostic variables that fulfilled all the criteria of information value

\begin{tabular}{clc}
\hline$x_{j t}$ & \multicolumn{1}{c}{ Final diagnostic variables } & $\begin{array}{c}\text { Classification of } \\
\text { the variable }\end{array}$ \\
\hline$x_{1 t}$ & Effectiveness of lobur force - product per hour worked & Stimulant \\
\hline$x_{4 t}$ & $\begin{array}{l}\text { Employment rate among people in the age 55 to 64 years (\% of } \\
\text { population) }\end{array}$ & Stimulant \\
\hline$X_{9 t}$ & $\begin{array}{l}\text { Educational attainment }-\% \text { of population in the age 25 to 34 with } \\
\text { tertiary education }\end{array}$ & Stimulant \\
\hline$x_{10 t}$ & $\begin{array}{l}\text { Participation rate in education and training population in the age from } \\
25 \text { to 64 years }\end{array}$ & Stimulant \\
\hline$x_{12 t}$ & $\begin{array}{l}\text { Total intramural R\&D expenditure (GERD) percentage of gross } \\
\text { domestic product (GDP) }\end{array}$ & Stimulant \\
\hline$x_{16 t}$ & $\begin{array}{l}\text { Tertiary graduates in science and technology per 1 000 inhabitants aged } \\
\text { 20-29 years }\end{array}$ & Stimulant \\
\hline
\end{tabular}

Source: own work. 
In the case of studies conducted for longer periods the sets of variables that fulfill all the three formal criteria are usually different in the analyzed years. As a result, the final decision on acceptance of a given variable to the final set of diagnostic variables can be based on the frequency of repetition of a given variable in the sets of accepted and rejected variables in the analyzed years (Zeliaś (ed.), 2000, pp. 127-133). Based on the described procedure it was necessary to reduce the set of potential variables to six variables that are given in the Table 2. All the final diagnostic variables were classified as stimulants.

In order to unify the diagnostic variables and make them comparable, the variables were standardized with application of classic standardization procedure given with equation 1 . This procedure enables to obtain the variables characterized with mean at the level 0 and variance that is equal to 1.

$$
x_{i j t}:=\frac{x_{i j t}-\overline{x_{j t}}}{s_{j t}} \quad i=1,2, \ldots . n, j=1,2, \ldots, p, t=1,2, . . l
$$

where $\overline{x_{j t}}$ and $s_{j t}$ are given with formulas 2 .

$$
\overline{x_{j t}}=\frac{1}{n} \sum_{i=1}^{n} x_{i j t}, s_{j t}=\sqrt{\frac{1}{n} \sum_{i=1}^{n}\left(x_{i j t}-\overline{x_{i j t}}\right)^{2}} \quad i=1,2, \ldots n, j=1,2, \ldots, p, t=1,2, . . l
$$

\section{Hellwig's Method of the Multiple-criteria Decision Analysis}

In current literature one can find a great variety of methods for multiple-criteria decision analysis and taxonomic research (Mardani et al., 2016, pp. 1-16; Mardani et al., 2015, pp. 4126-4148; Zavadskas et al., 2014, pp. 165-179; Balcerzak \& Pietrzak, 2016e; Pietrzak \& Balcerzak, 2016d; Jantoń-Drozdowska \& Majewska, 2015, pp. 61-83; Jurkowska, 2014, pp. 49-73; Mościbrodzka, 2014, pp. 29-47; Streimikiene et al., 2011, pp. 148-164; Kaplikski, Tupenaite, 2011, pp. 165-168; Zvirblis, Buracas, 2012, pp. 124-138; Streimiikiene, Balzentiene, 2012, pp. 333-344; Bauers, Zavadskas, 2010, pp. 67-84).

In the case of current research Hellwig's method of taxonomic measure of development with constant pattern (ideal solution) for the entire period was used. The application of constant pattern was the condition for dynamic comparison of the research results. Additionally, it enabled to obtain time series that can be used as an input data for future econometric research, which was stated as the additional operational aim of the paper.

The proposed method is very close to Technique for Order of Preference by Similarity to Ideal Solution (TOPSIS), which is based on a concept of similarity to ideal solution, and which is currently commonly applied in multiple-criteria decision-making (MCDM) (Hwang \& Yoon, 1981; Yoon \& Hwang, 1995). However, Hellwig's method was developed a few decades before TOPSIS. It was originally proposed in 1968 as a taxonomic method for international comparisons of economic development of countries (Hellwig, 1968, pp. 323326). It was disseminated in the international literature in 1972 with realization of UNESCO research project on the human resources indicators for less developed countries (Hellwig, 1972b, pp. 115-134). The main advantages of the method are high elasticity and methodological simplicity, which is crucial in the case of multiple-criteria decision analysis.

The core of the Hellwig's concept is a construction of synthetic variable (the taxonomic measure of economic development - TMD) that is designed as a distance from the abstract pattern of economic development (ideal solution). In this approach it is determined with formulas 1 and 2 . 


$$
\begin{aligned}
& x_{0 j t}=\max _{i t} x_{i j t} \text { for } \quad j \in S, \quad i=1,2, \ldots, n ; j=1,2, \ldots, p ; t=1,2, \ldots, l, \\
& x_{0 j t}=\min _{i t} x_{i j t} \text { for } \quad j \in D, \quad i=1,2, \ldots, n ; j=1,2, \ldots, p ; t=1,2, \ldots, l,
\end{aligned}
$$

where S relates to a set of standardized stimulants and D relates to a set of standardized disstimulants.

The main difference between the Hellwig's method and the TOPSIS relates to the construction of the pattern of economic development (ideal solution). In the case of TOPSIS method not only positive ideal solution but also negative ideal solution is taken into consideration.

The distance from the pattern of economic development is estimated with the equation 3.

$$
d_{i 0 t}=\sqrt{\sum_{j=1}^{p}\left(x_{i j t}-x_{0 j t}\right)^{2}} \quad i=1,2, \ldots, n ; j=1,2, \ldots, p ; t=1,2, \ldots, l .
$$

TMD is given with formula 4 .

$$
d_{i t}=1-\frac{d_{i 0 t}}{d_{0 t}} \quad i=1,2, \ldots, n ; j=1,2, \ldots, p ; t=1,2, \ldots, l,
$$

where $d_{0 t}=\bar{d}_{0 t}+2 s_{d t}$, and $\overline{d_{0 t}}, s_{d t}$ are given with formula (5).

$$
\overline{d_{0 t}}=\frac{1}{n} \sum_{i=1}^{n} d_{i 0 t}, s_{d t}=\sqrt{\frac{1}{n} \sum_{i=1}^{n}\left(d_{i 0 t}-\overline{d_{0 t}}\right)^{2}} \quad i=1,2, \ldots, n ; t=1,2, \ldots, l .
$$

The proposed method enables to group the countries into relatively homogenous subsets (classes) and propose rankings of the countries for the analyzed period. The rankings of the countries in the years 2001-2012 are presented in Table $3 a$ (in Annex) and $3 b$ (in Annex).

In the next stage the countries were grouped into five classes:

1. the countries with very high level of TMD for the QHC;

2. the countries with a high level of the measure;

3. the countries with an average level of the measure;

4. the countries with a low level of the measure;

5. the countries with a very low level of the measure.

In order to group the countries into relatively homogenous sub-sets the method of natural breaks (Jenks optimization method) was used. The main idea of the natural breaks method consists of minimization of variance for objects from the chosen subsets and maximization of variance between the subsets (Jenks, 1967, pp. 186-190). In order to catch the potential impact of the last global financial crisis, which was the additional objective of the article, the years 2001-2011 were divided into two sub-periods 2001-2007 and 2007-2011. The grouping was conducted for the years 2001, 2007 and 2011. The results of application of natural breaks method are presented in the Figure 1.

Then, the dynamics of the value of TMD in the years 2001-2007, 2007-2012 and 2001-2012 was estimated. In that case also natural breaks method was applied for grouping the countries into three sub-sets that can be characterised with:

1. high dynamics of the value of TMD; 
2. average dynamics of the value of the measure;

3. low dynamics of the value of the measure.

The results are presented in Figure 2 and Table 4.

\section{Discussion on the Research Results}

As it has been already mentioned in the methodological part of the article, the biggest weakness of every multiple-criteria analysis is a great sensitivity of final results to the differences in selection of potential diagnostic variables. Thus, the rankings and specific positions of given countries should be always treated with great caution. However, in spite of this weakness the conducted analysis can still show the structure and long term path of development of a phenomenon under evaluation. As a result, the analysis of the results of the conducted research concentrates on this perspective.

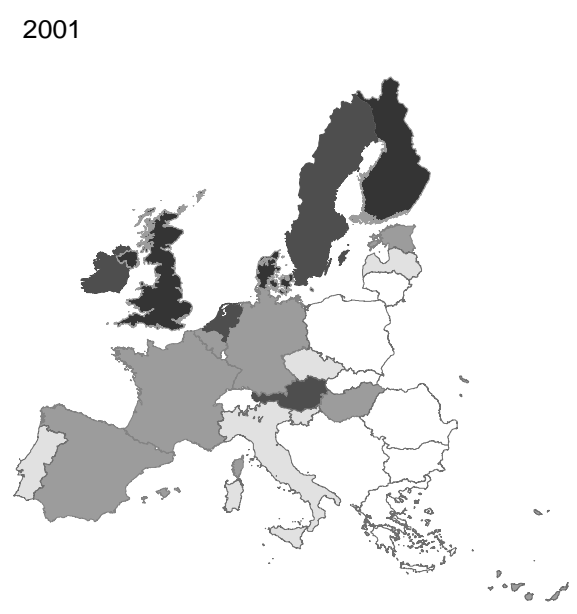

2012

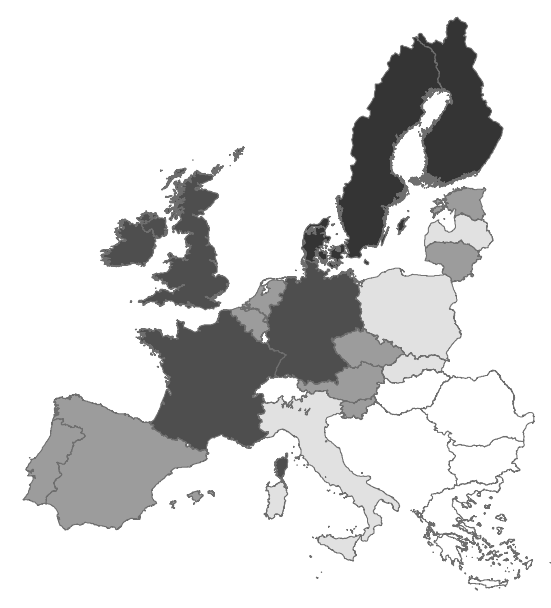

2007

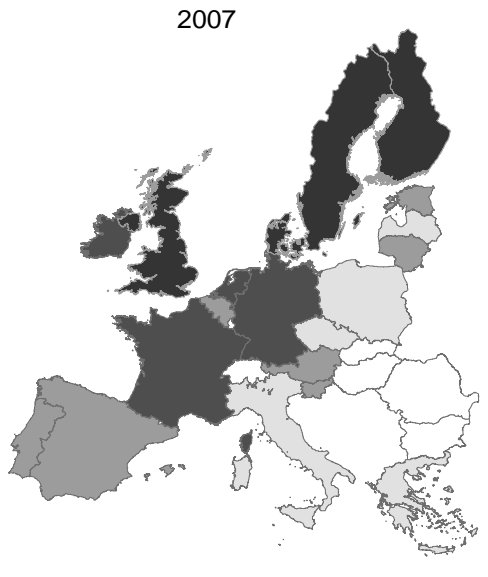

Value of TMD for Quality of Human Capital

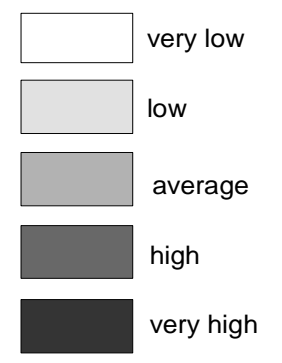

$\therefore \sigma_{0}$

Figure 1. Value of TMD for Quality of Human Capital in the years 2001, 2007 and 2012 Source: own estimation based on Eurostat data.

The results presented in Table $3 a$ (in Annex) and $3 b$ (in Annex) and Figure 1 show that in the last year of the research the EU countries can be generally classified to the following sub-sets: 
Scandinavian countries that are the leaders in terms of the QHC and should be treated as a benchmark for good practices, in the second subset one can find mainly the northern developed European economies that are characterized with relatively high level of the measure of the QHC. In this group one can find Great Britain, Ireland, France and Germany. The results of these economies are quite stable and they are the leaders in the whole period, which is quite natural when one takes into consideration their level of development and economic role in the EU.

However, more dynamic results one can see in the case of the next three subsets grouping the countries from average to very low level of the value of the TMD for the QHC. In the last year in the sub-sets with the average and low level of obtained measure one can find Spain, Portugal, Austria, with the exception of Hungary the Central European economies that joined the EU in the year 2004 and Italy. In this group special attention should be given to relatively good results obtained by Estonia, Latvia, Czech Republic and Slovenia that in comparison with the starting point were able to improve significantly their results.

In the last group characterized with the lowest level of measure of the TMD one can find Hungary, Romania and Bulgaria and Greece. In this group the lowest position of Hungary can be considered as quite unexpected result. This low rank is mostly the consequence of relatively weak results of this country in the case of participation rate in education and training and the worst results in the number of tertiary graduates in science and technology, which in the whole period was much below the average.

Table 4. Dynamics of value of TMD for Quality of Human Capital in the years 2001-2007, 2007-2012 and 2001-2012

\begin{tabular}{|c|c|c|c|c|c|c|c|c|}
\hline $\begin{array}{l}\text { Count- } \\
\text { ry }\end{array}$ & $\begin{array}{l}2001- \\
2007\end{array}$ & $\begin{array}{c}\text { Classifica- } \\
\text { tion }\end{array}$ & $\begin{array}{l}\text { Count- } \\
\text { ry }\end{array}$ & $\begin{array}{l}2007- \\
2012\end{array}$ & $\begin{array}{l}\text { Classifica- } \\
\text { tion }\end{array}$ & $\begin{array}{l}\text { Count- } \\
\text { ry }\end{array}$ & $\begin{array}{l}2001- \\
2012\end{array}$ & $\begin{array}{c}\text { Classifica- } \\
\text { tion }\end{array}$ \\
\hline $\mathrm{EE}$ & $18,01 \%$ & High & $\mathrm{CZ}$ & $24,90 \%$ & High & $\mathrm{CZ}$ & $33,72 \%$ & High \\
\hline LT & $15,73 \%$ & High & SK & $22,89 \%$ & High & SK & $26,19 \%$ & High \\
\hline PT & $15,25 \%$ & High & SI & $18,32 \%$ & High & SI & $23,96 \%$ & High \\
\hline $\mathrm{LV}$ & $10,90 \%$ & High & PL & $16,34 \%$ & High & $\mathrm{EE}$ & $19,48 \%$ & High \\
\hline $\mathrm{CZ}$ & $7,06 \%$ & High & $\overline{\mathrm{DE}}$ & $6,67 \%$ & Average & PT & $18,39 \%$ & High \\
\hline SI & $4,76 \%$ & Average & PT & $2,73 \%$ & Average & PL & $16,35 \%$ & High \\
\hline DK & $4,29 \%$ & Average & AT & $1,93 \%$ & Average & $\mathrm{DE}$ & $6,38 \%$ & Average \\
\hline FI & $3,69 \%$ & Average & $\mathrm{EE}$ & $1,25 \%$ & Average & LT & $4,71 \%$ & Average \\
\hline SK & $2,68 \%$ & Average & SE & $-2,85 \%$ & Average & DK & $1,29 \%$ & Average \\
\hline IT & $1,11 \%$ & Average & $\overline{\mathrm{DK}}$ & $-2,88 \%$ & Average & $\mathrm{LV}$ & $-1,25 \%$ & Average \\
\hline FR & $0,11 \%$ & Average & FR & $-3,24 \%$ & Average & FI & $-2,20 \%$ & Average \\
\hline PL & $0,00 \%$ & Average & FI & $-5,68 \%$ & Average & FR & $-3,14 \%$ & Average \\
\hline IE & $-0,22 \%$ & Average & IE & $-8,37 \%$ & Average & AT & $-3,57 \%$ & Average \\
\hline$\overline{\mathrm{DE}}$ & $-0,27 \%$ & Average & LT & $-9,53 \%$ & Average & SE & $-8,22 \%$ & Average \\
\hline ES & $-1,81 \%$ & Average & $\mathrm{NL}$ & $-10,69 \%$ & Average & IE & $-8,57 \%$ & Average \\
\hline $\mathrm{RO}$ & $-2,65 \%$ & Average & $\mathrm{LV}$ & $-10,95 \%$ & Average & ES & $-12,58 \%$ & Average \\
\hline $\mathrm{BE}$ & $-3,19 \%$ & Low & ES & $-10,96 \%$ & Average & NL & $-15,88 \%$ & Average \\
\hline AT & $-5,39 \%$ & Low & UK & $-15,51 \%$ & Low & $\mathrm{BE}$ & $-20,79 \%$ & Low \\
\hline SE & $-5,52 \%$ & Low & $\mathrm{BE}$ & $-18,18 \%$ & Low & UK & $-22,69 \%$ & Low \\
\hline $\mathrm{NL}$ & $-5,81 \%$ & Low & GR & $-19,97 \%$ & Low & IT & $-23,13 \%$ & Low \\
\hline UK & $-8,50 \%$ & Low & BG & $-20,63 \%$ & Low & $\mathrm{RO}$ & $-24,56 \%$ & Low \\
\hline BG & $-13,76 \%$ & Low & RO & $-22,51 \%$ & Low & BG & $-31,55 \%$ & Low \\
\hline $\mathrm{HU}$ & $-23,36 \%$ & Low & IT & $-23,97 \%$ & Low & $\mathrm{HU}$ & $-42,25 \%$ & Low \\
\hline GR & $-27,86 \%$ & Low & $\mathrm{HU}$ & $-24,65 \%$ & Low & GR & $-42,27 \%$ & Low \\
\hline
\end{tabular}

Source: own estimation based on Eurostat data. 

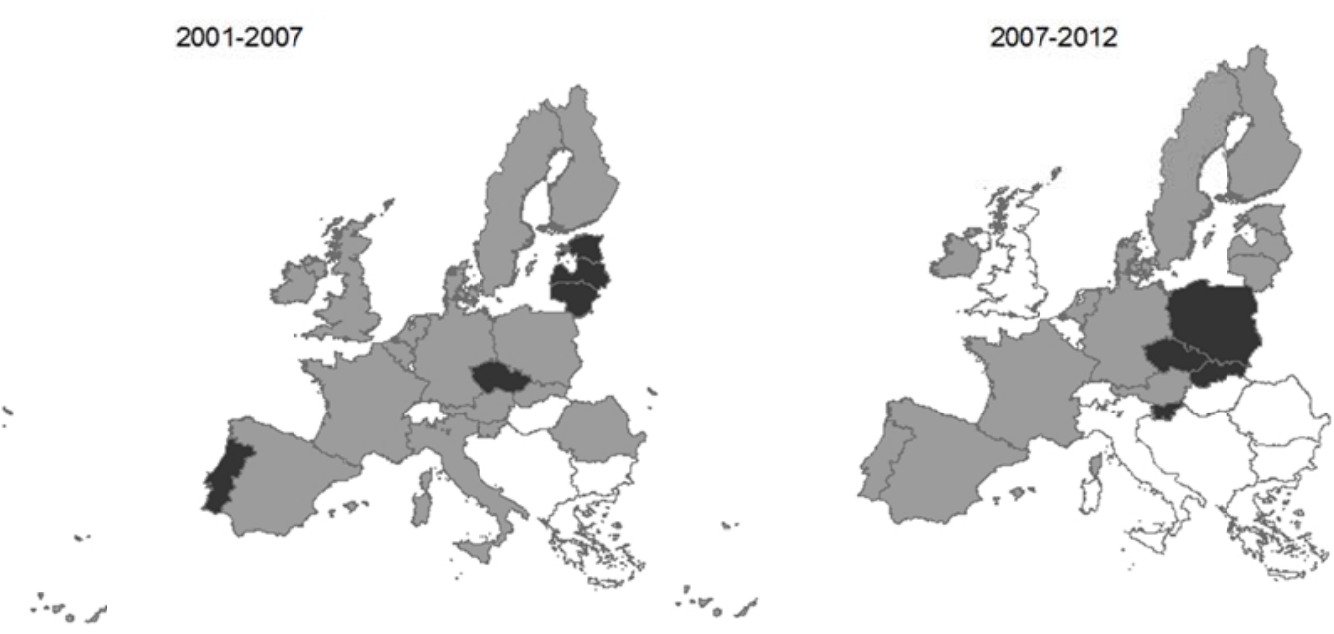

2001-2012

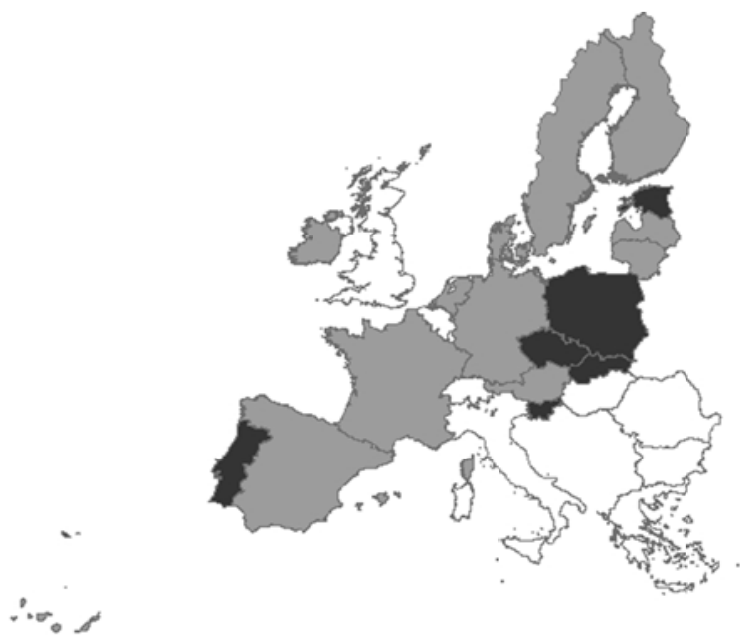

Dynamics of TMD for Quality of Human Capital

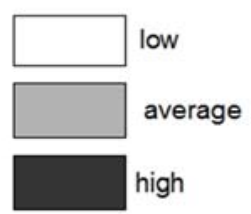

Figure 2. Dynamics of value of TMD for Quality of Human Capital in the years 2001-2007, 2007-2012 and 2001-2012

Source: own estimation based on Eurostat data.

The dynamics of the value of the TMD, which is presented in Table 4 and Figure 2, shows that the biggest improvement was obtained by Portugal as the only old member country and new member states such as Baltic countries, Poland, Czech Republic, Slovakia and Slovenia. These results could be interpreted as quite natural as in the first year of the analysis the new member states generally started from relatively low level of the value of the TMD. Thus, it could be only treated as a statistical low base effect or simple result of caching up process. However, when one looks at the results of Estonia that was rated in the first year in the third group of countries with average level of the value of the TMD or the results of Slovenia and Czech Republic that were classified in the same group as Italy and Portugal, the explanations concentrating on the simple statistical effect cannot be easily accepted. Additionally, the data on the dynamics of the TMD shows that such new members as Romania, Bulgaria and Hungary were not able to improve their results. This divergence in relation to the value of the TMD among the new member states shows that the improvements 
of the QHC at macroeconomic level can be strongly influenced by institutional and policy factors that should be the subject of future detailed research.

The comparison of the dynamics of the value of the TMD in the years 2001-2007 and 2007-2011 can be useful in looking for potential influence of the last global financial crisis on the changes of the QHC at macroeconomic level. The data presented in table 4 confirms that with the exception of Portugal the countries seriously affected by the crisis in the second subperiod were characterised with significantly bigger decreases of the value of the TMD than in the years 2001-2007. Greece makes the most obvious example here, but it can be also seen in the case of Italy, Spain, Ireland and Great Britain. The opposite situation can be seen in the case of the new member states that were not so much negatively affected by the crisis as the old Europe. The dynamics of their values of the TMD was generally higher in the second subperiod. These factors can confirm the influence of the global financial crisis on the relative level of the QHC form macroeconomic perspective.

\section{Conclusions}

The main objective of the article was the multiple-criteria analysis of the QHC in the EU countries at macroeconomic level. In this regard the application of taxonomic Hellwig's method of measure of development with the constant pattern enabled to conduct the dynamic analysis in the years 2001-2011 and to evaluate the relative changes of the phenomenon in that period. Additionally the obtained time series can be used in future econometric research.

In regard to the results obtained by the new member states there is a visible divergence between these economies. Baltic countries, Slovenia, Poland, Czech Republic and Slovakia were able to improve their scores significantly, whereas Hungary, Romania and Bulgaria were not able to do so. This divergence confirms that the relative changes of the QHC at the macroeconomic level cannot be simply attributed to statistical effects, the "convergence" or caching up process, but they can be a consequence of institutional or policy factors.

Lastly the analysis of dynamics of the measure for the QHC was conducted for two sub-periods for the years 2001-2007 and 2007-2011. This approach confirmed that the economies, which were strongly touched by the global financial crisis, with the exception of Portugal were also characterized with serious decreases of the value of the TMD for the QHC at macroeconomic level.

\section{References}

Balcerzak, A. P. (2009), Effectiveness of the Institutional System Related to the Potential of the Knowledge Based Economy, Ekonomista, 6, pp. 711-739.

Balcerzak, A. P. (ed.) (2009), Polski rynek pracy w warunkach integracji europejskiej, Toruń: Wydawnictwo Adam Marszałek.

Balcerzak, A. P. (2011), Taksonomiczna analiza jakości kapitału ludzkiego w Unii Europejskiej w latach 2002-2008, Prace Naukowe Uniwersytetu Ekonomicznego we Wrocławiu, Taksonomia 18 Klasyfikacja i analiza danych - teoria i zastosowania, 176, pp. 456-467.

Balcerzak, A. P. (2015), Europe 2020 Strategy and Structural Diversity Between Old and New Member States. Application of Zero-unitarizatin Method for Dynamic Analysis in the Years 2004-2013, Economics \& Sociology, 8(2), pp. 190-210. DOI: dx.doi.org/10.14254/2071-789X.2015/8-2/14.

Balcerzak, A. P. \& Pietrzak, M. B. (2015), Quality of Institutional Systems for Global Knowledge-based Economy and Convergence Process in the European Union, 
Ekonomia. Rynek, Gospodarka, Spoleczeństwo, 42, pp. 93-106, DOI: http://dx.doi.org/10.17451/eko/42/2015/173.

Balcerzak, A. P. \& Pietrzak, M. B. (2016a), Human Development and Quality of Institutions in Highly Developed Countries, In: M. H. Bilgin, H. Danis, E. Demir, and U. Can (eds.), Financial Environment and Business Development. Proceedings of the 16th Eurasia Business and Economics Society, Springer International Publishing.

Balcerzak, A. P. \& Pietrzak, M. B. (2016b), Quality of Institutions and Total Factor Productivity in European Union, Statistics in Transition new series, 17(3).

Balcerzak, A. P. \& Pietrzak, M. B. (2016c), Quality of Human Capital in European Union in the Years 2004-2013. Application of Structural Equation Modeling, In: Proceedings of the International Scientific Conference Quantitative Methods in Economics Multiple Criteria Decision Making XVIII, Vratna: Letra Interactive, pp. 7-12.

Balcerzak, A. P. \& Pietrzak, M. B. (2016d), Structural Equation Modeling in Evaluation of Technological Potential of European Union Countries in the Years 2008-2012, In: M. Papież \& S. Śmiech (eds.), The 10th Professor Aleksander Zelias International Conference on Modelling and Forecasting of Socio-Economic Phenomena. Conference Proceedings, Cracow: Foundation of the Cracow University of Economics, pp. 9-18.

Balcerzak, A. P. \& Pietrzak, M. B. (2016e), Application of TOPSIS Method for Analysis of Sustainable Development in European Union Countries, In: T. Loster \& T. Pavelka (eds.), The 10th International Days of Statistics and Economics. Conference Proceedings, September 8-10, 2016, Prague.

Balcerzak, A. P., Pietrzak, M. B. \& Rogalska, E. (2016), Fiscal Contractions in Eurozone in the years 1995-2012: Can non-Keynesian effects be helpful in future deleverage process? In: M. H. Bilgin, H. Danis, E. Demir, and U. Can (eds.), Business Challenges in the Changing Economic Landscape - Vol. 1. Proceedings of the 14th Eurasia Business and Economics Society, Springer International Publishing, pp. 483-496, DOI: 10.1007/978-3-319-22596-8_35.

Balcerzak, A. P. \& Rogalska, E. (2016), Non-Keynesian Effects of Fiscal Consolidations in Central Europe in the Years 2000-2013, In: M. H. Bilgin \& H. Danis (eds.), Entrepreneurship, Business and Economics - Vol. 2. Proceedings of the 15th Eurasia Business and Economics Society, Springer International Publishing, pp. 271-282, DOI: 10.1007/978-3-319-27573-4_18.

Balcerzak, A. P. \& Żurek, M. (2011), Foreign Direct Investment and Unemployment: VAR Analysis for Poland in the Years 1995-2009, European Research Studies, 14(1), pp. 314.

Bauers, W. K. M., Zavadskas, E. K. (2010), Robustness in the Multimoora Model: the example of Tanzania, Transformation in Business and Economics, 9(3), pp. 67-84.

Ciborowski R. (2014), Innovation Process Adjusting in Peripheral Regions. The Case of Podlaskie Voivodship, Equilibrium. Quarterly Journal of Economics and Economic Policy, 9(2), pp. 57-72, DOI: http://dx.doi.org/10.12775/EQUIL.2014.011.

Cichy, K. (2009), Human Capital and Technological Progress as the Determinants of Economic Growth, National Bank of Poland Working Paper, 60.

Cichy, K. \& Malaga, K. (2006), The quantity and quality of human capital in Poland and USA analyzed in the framework of the Manuelli-Seshadri model, PUE Review, 6(1), pp. 5-24.

David, P. A. \& Goddard Lopez, J. G. (2001), Knowledge, Capabilities and Human Capital Formation in Economic Growth, New Zealand Treasury Working Paper, 01/13, June.

European Commission (2010), Europe 2020 A strategy for smart, sustainable and inclusive growth, Communication from the commission, Brussels, 3.3.2010 COM(2010) 2020. 
Florczak, W. (2007), Kapitał ludzki a rozwój gospodarczy, In: W. Welfe (ed.), Gospodarka oparta na wiedzy, Warszawa: Polskie Wydawnictwo Ekonomiczne.

Gostkowski, Z. (1972), Problems and Difficulties in the Elaboration of a Coherent System of Human Capital Resources Indicators for Less Developed Countries, In: Z. Gostkowski (ed.), Towards a System of Human Capital Resources Indicators for Less Developed Countries. Papers Prepared for a UNESCO Research Project, Wrocław: Ossolineum, Polish Academy of Sciences Press.

Hellwig, Z. (1968), Zastosowanie metody taksonomicznej do typologicznego podziału krajów ze względu na poziom ich rozwoju oraz zasoby i strukturę wykwalifikowanych kadr, Przeglad Statystyczny, 4, pp. 307-327.

Hellwig, Z. (1972a), On the Optimal Choice of Predictors, In: Z. Gostkowski (ed.), Towards a System of Human Capital Resources Indicators for Less Developed Countries. Papers Prepared for a UNESCO Research Project, Wrocław: Ossolineum, Polish Academy of Sciences Press, pp. 69-90.

Hellwig, Z. (1972b), Procedure of Evaluating High-Level Manpower Data and Typology of Countries by Means of the Taxonomic Method, In: Z. Gostowski (ed.), Towards a System of Human Resources Indicators for Less Developed Countries, Papers Prepared for a UNESCO Research Project, Wrocław: Ossolineum-The Polish Academy of Sciences, pp. 115-134.

Hobza, A., \& Mourre, G. (2010), Quantifying the potential macroeconomic effects of the Europe 2020 strategy: stylised scenarios, European Economy, Economic Papers 424, September.

Hwang, C. L., \& Yoon, K. (1981), Multiple attribute decision making: Methods and applications A State-of-the-Art Survey, Heidelberg: Springer, http://dx.doi.org/10.1007/978-3-642-48318-9.

Jantoń-Drozdowska, E. \& Majewska, M. (2015), Social Capital as a Key Driver of Productivity Growth of the Economy: Across-countries Comparison, Equilibrium. Quarterly Journal of Economics and Economic Policy, 10(4), pp. 61-83, DOI: http://dx.doi.org/10.12775/ EQUIL.2015.035.

Jenks, G. F. (1967), The Data Model Concept in Statistical Mapping, International Yearbook of Cartography, 7, pp. 186-190.

Jurkowska, B. (2014), The Federal States of Germany - Analysis and Measurement of Development using Taxonomic Methods, Oeconomia Copernicana, 5(3), pp. 49-73, DOI: http://dx.doi.org/10.12775/OeC.2014.019.

Kaplikski, O, Tupenaite, A. (2011), Review of the Multiple Criteria Decision Making Methods, Intelligent and Biometric Systems Applied in Modern Construction Economics, Transformation in Business and Economics, 10 (1), pp. 166-182.

Kunasz, M. (2009), Ranking wykorzystania zasobów ludzkich w krajach Unii Europejskiej, In: E. Okoń-Horodyńska \& R. Wisła (eds.), Kapitał intelektualny i jego ochrona, Warszawa: Instytut Wiedzy i Innowacji, pp. 35-48.

Laroche, M., Merette, M., \& Ruggeri, G. C. (1999), On the Concept and Dimensions of Human Capital in a Knowledge Based Economy Context, Canadian Public Policy, 25(1), pp. 87-100. DOI: 10.2307/3551403.

Libertowska, A. (2014), Social Capital in Knowledge Based Economy. Chosen Aspects, Oeconomia Copernicana, 5(3), pp. 93-107, DOI: http://dx.doi.org/10.12775 /OeC.2014.021.

Madrak-Grochowska, M. (2015), The Knowledge-based Economy as a Stage in the Development of the Economy, Oeconomia Copernicana, 6(2), pp. 7-21, DOI: http://dx.doi.org/10. 12775/OeC.2015.009. 
Mardani, A., Jusoh, A., \& Zavadskas, E. K. (2015), Fuzzy multiple criteria decision-making techniques and applications - Two decades review from 1994 to 2014, Expert Systems with Applications, 42(8), pp. 4126-4148. DOI:10.1016/j.eswa.2015.01.003.

Mardani, A., Jusoh, A., Zavadskas, E. K., Zakuan, N., Valipour, A., \& Kazemilari, M. (2016), Proposing a new hierarchical framework for the evaluation of quality management practices: a new combined fuzzy hybrid MCDM approach, Journal of Business Economics and Management, 17(1), pp. 1-16. DOI:10.3846/16111699.2015.1061589.

Mościbrodzka, M. (2014), The Use of Methods of Multidimensional Comparative Analysis in Evaluation of the Standard of Living of Poland's Population in Comparison with Other Countries of the European Union, Oeconomia Copernicana, 5(3), pp. 29-47, DOI: http://dx.doi.org/10.12775/OeC.2014.018.

Müller-Frączek, I., \& Pietrzak, M. B. (2011), Przestrzenna analiza stopy bezrobocia w Polsce w latach 2004-2008, In: P. Jedlicka (ed.), Hradecké ekonomické dny 2011. Ekonomický rozvoj a management regionu, Gaudeamus, Hradec Králové, pp. 205-209.

Okoń-Horodyńska, E., \& Wisła, R. (eds.) (2010), Kapitał intelektualny i jego ochrona, Warszawa: Instytut Wiedzy i Innowacji.

Pawlas, I. (2009), Kapitał ludzki w krajach Unii Europejskiej w świetle badań taksonomicznych, In: D. Kopycińska (ed.), Kapitał ludzki jako czynnik przewagi konkurencyjnej, Szczecin: Katedra Mikroekonomii Uniwersytetu Szczecińskiego, pp. 21-31.

Pietrzak, M. B. \& Balcerzak, A. P. (2016a), A Spatial SAR Model in Evaluating Influence of Entrepreneurship and Investments on Unemployment in Poland, In: Proceedings of the International Scientific Conference Quantitative Methods in Economics Multiple Criteria Decision Making XVIII, Vratna: Letra Interactive, pp. 303-308.

Pietrzak, M. B. \& Balcerzak, A. P. (2016b), Quality of Human Capital and Total Factor Productivity in New European Union Member States, In: T. Loster \& T. Pavelka (eds.), The 10th International Days of Statistics and Economics. Conference Proceedings, September 8-10, 2016. Prague.

Pietrzak, M. B., \& Balcerzak, A. P. (2016c), Assessment of Socio-Economic Sustainability in New European Union Members States in the years 2004-2012, In: M. Papież \& S. Śmiech (eds.), The 10th Professor Aleksander Zelias International Conference on Modelling and Forecasting of Socio-Economic Phenomena. Conference Proceedings, Cracow: Foundation of the Cracow University of Economics, pp. 120-129.

Pietrzak. M. B. \& Balcerzak, A. P. (2016d), Socio-economic Sustainability in Poland. SEM Analysis at Regional Level, Institute of Economic Research Working Papers, No. 20/2016. Retrieved form http://econpapers.repec.org/paper/peswpaper/2016_3ano20.htm.

Pietrzak, M. B., Wilk, J., Kossowski, T., \& Bivand, R. (2014), The identification of spatial dependence in the analysis of regional economic development - join-count test application, In: M. Papież, \& S. Śmiech (eds.), Proceedings of the 8th Professor Aleksander Zelias International Conference on Modelling and Forecasting of SocioEconomic Phenomena, Cracow: Foundation of the Cracow University of Economics, pp. 135-144.

Sachpazidu-Wójcicka, K. (2014), Conditions for Innovativeness of Industrial Entrepreneurs in Poland, Equilibrium. Quarterly Journal of Economics and Economic Policy, 9(2), pp. 93-107, DOI: http://dx.doi.org/10.12775/EQUIL.2014.013.

Stankiewicz, J., \& Moczulska, M. (2015), The Involvement of Employees in Knowledge Management in the Light of the Research Results, Oeconomia Copernicana, 6(2), pp. 37-51, DOI: http://dx.doi.org/10. 12775/OeC.2015.011. 
Streimikiene, D. (2013), Assessment of road transport technologies based on GHG emission reduction potential and costs, Transformation in Business and Economics, 12 (29), pp. 138-148.

Streimikiene, D, Balezentiene, L. (2012), Assessment of Electricity Generation Technologies Based on GHG Emission Reduction Potential and Costs, Transformation in Business and Economics, 11 (2A), pp. 333-344.

Streimikiene, D, Mikalauskiene, A, Barakauskaite-Jakubauskiene (2011), Sustainability Assessment of Policy Scenarios, Transformation in Business and Economics, 10 (2), pp. 148-165.

Wilk, J., Pietrzak, M. B., \& Siekaniec, M. (2013), The impact of metropolitan areas on internal migrations in Poland. The case of southern regions, In: M. Papież, \& S. Śmiech (eds.), Proceedings of the 7th Professor Aleksander Zelias International Conference on Modelling and Forecasting of Socio-Economic Phenomena, Cracow: Foundation of the Cracow University of Economics, pp. 124-132.

Wronowska, G. (2009), Kapitał ludzki w krajach Unii Europejskiej - analiza porównawcza, In: D. Kopycińska (ed.), Kapitał ludzki jako czynnik przewagi konkurencyjnej, Szczecin: Katedra Mikroekonomii Uniwersytetu Szczecińskiego, pp. 32-45.

Wronowska, G. (2015), Welfare and Higher Education in EU Member States - Comparative Analysis, Oeconomia Copernicana, 6(1), pp. 33-45, DOI: http://dx.doi.org/10. 12775/OeC.2015.002.

Yoon, K. P., \& Hwang, C. L. (1995), Multiple Attribute Decision Making: An Introduction, Thousand Oaks: CA Sage Pub.

Zeliaś, A. (ed.) (2000), Taksonomiczna analiza przestrzennego zróżnicowania poziomu życia w Polsce w ujęciu dynamicznym, Kraków: Wydawnictwo Akademii Ekonomicznej w Krakowie.

Zavadskas, E. K., Turskis, Z., \& Kildiene, S. (2014), State of art surveys of overviews on MCDM/MADM methods, Technological and Economic Development of Economy, 20(1), pp. 165-179. DOI:10.3846/20294913.2014.892037.

Zvirblis, A, Buracas, A. (2012), Multiple Criteria Assessment of the Country's Knowledge Economy Determinants, Transformation in Business and Economics, 11 (3), pp. 124138. 


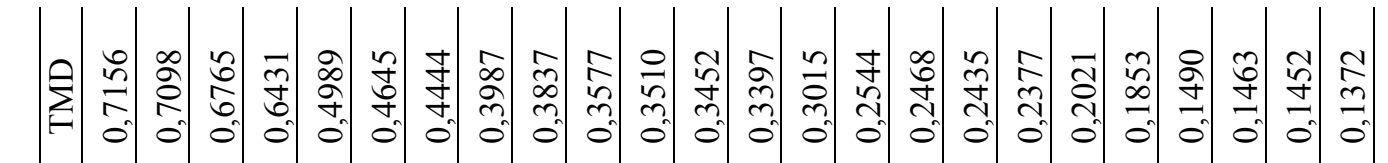
๕ั้

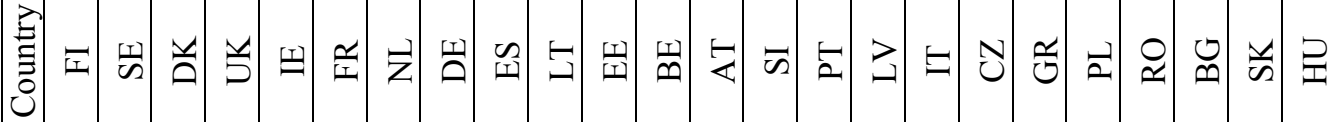

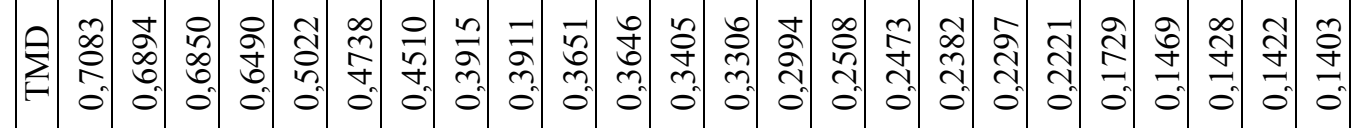
$\stackrel{\leftrightarrow}{\circ}$

๖

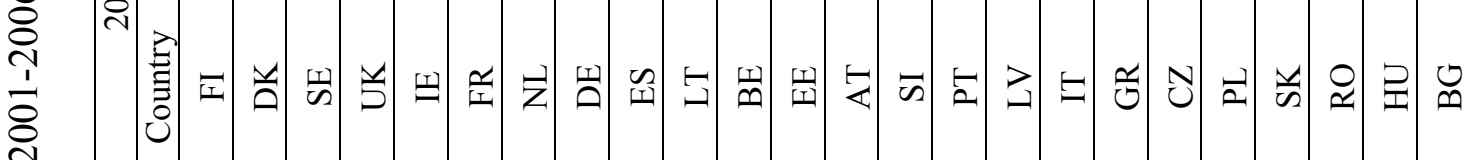

$\stackrel{\infty}{\stackrel{\Xi}{\sharp}}$

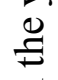

.

苍

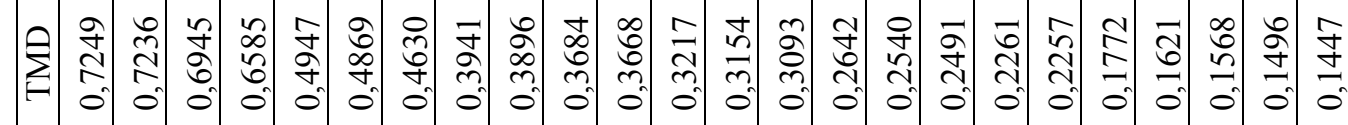

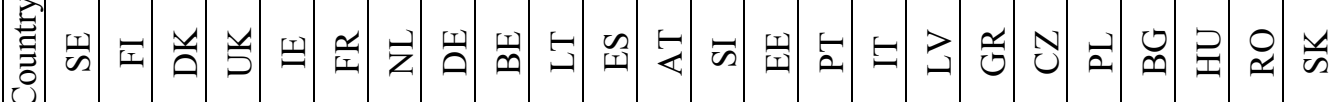

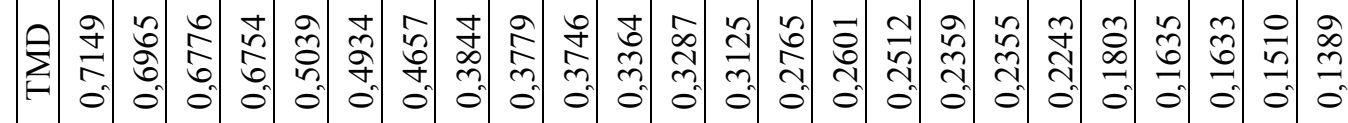

ชి

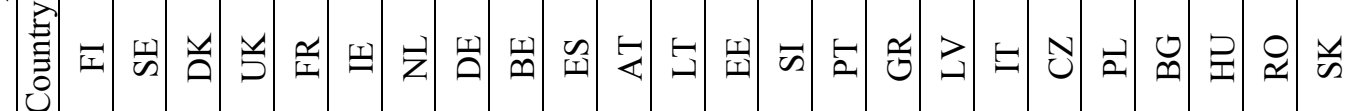

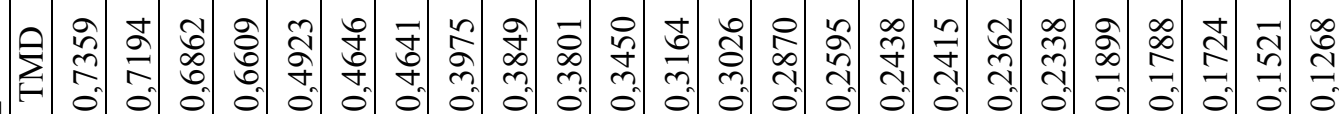

กิ่

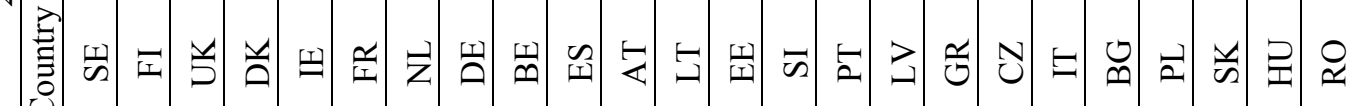

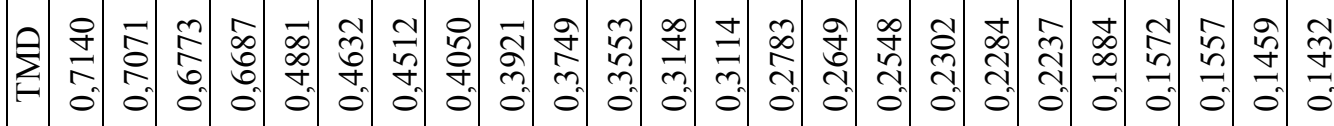
ㅎํำ

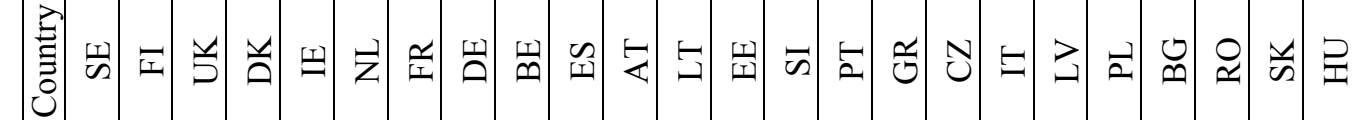

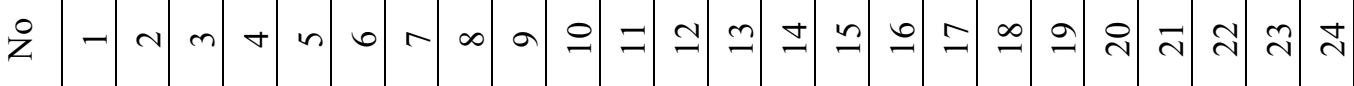




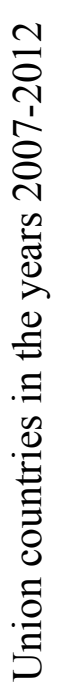

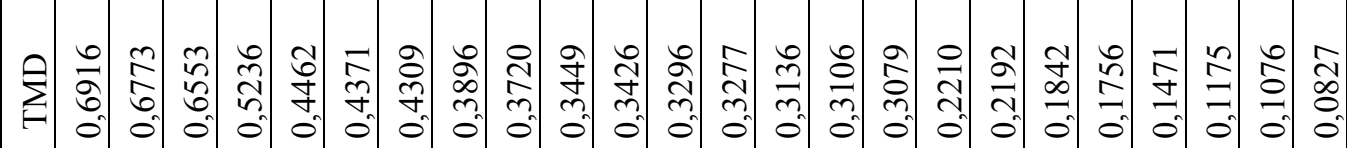
$\stackrel{\sim}{\overparen{0}}$

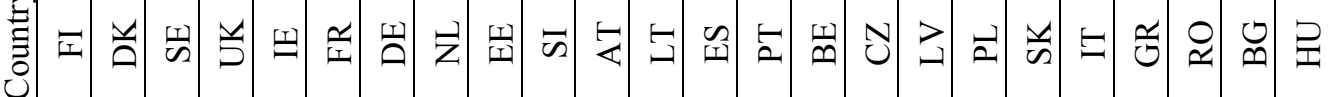

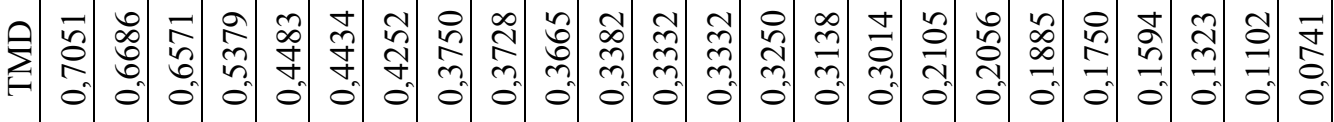

흥

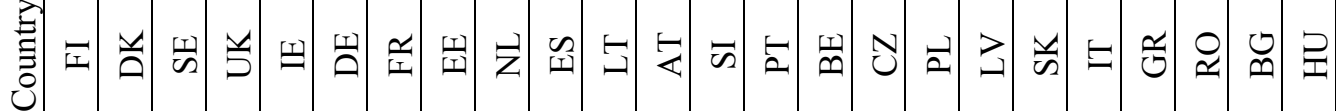

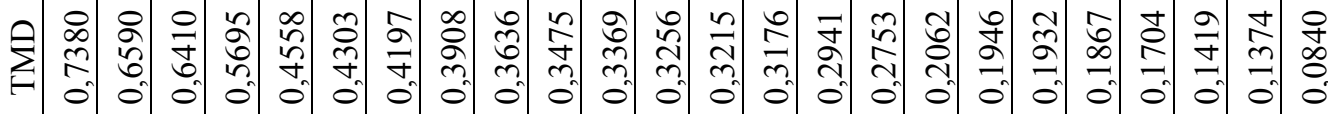

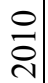

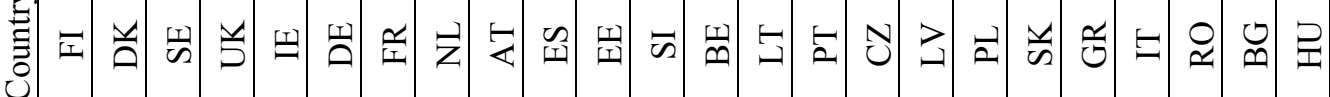

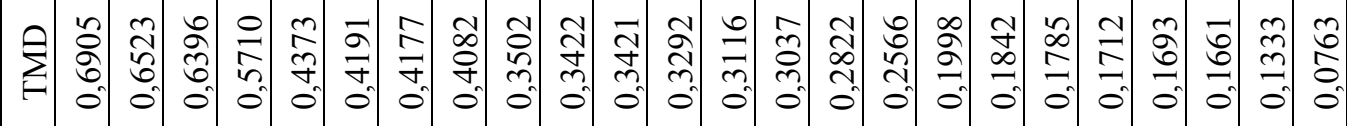
ڤे

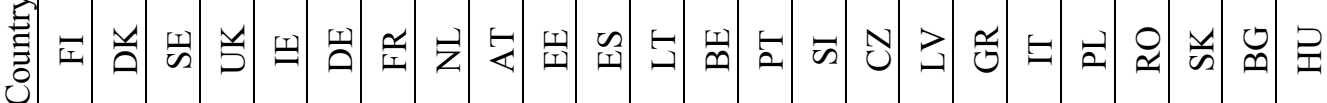

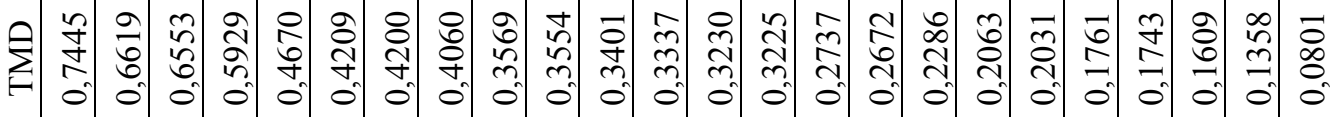

ڤे

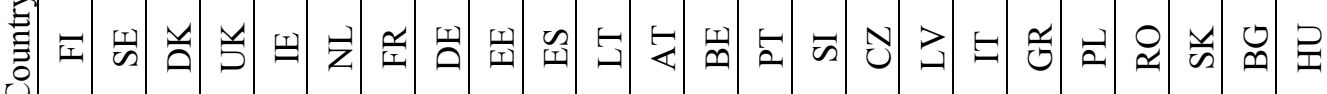

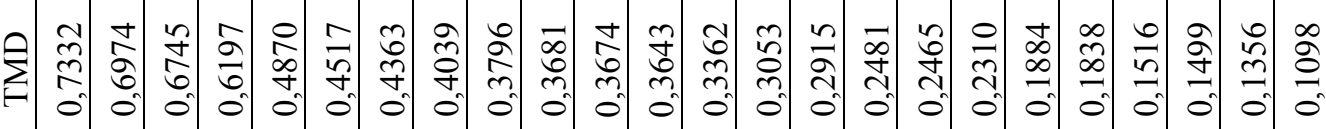

ڤิ)

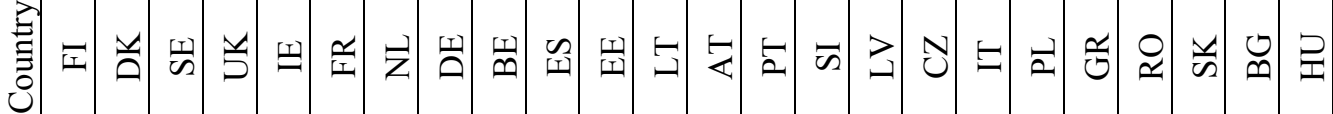

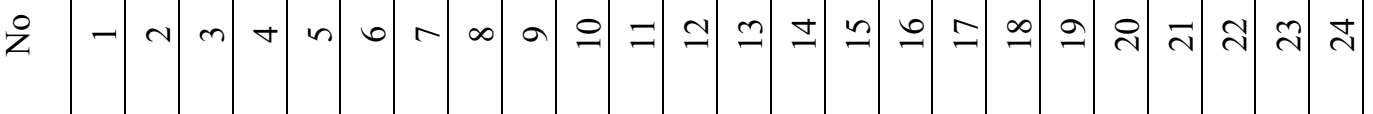

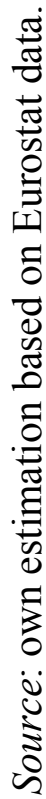

